\title{
Ethics of embryonic stem cell research according to Buddhist, Hindu, Catholic, and Islamic religions: perspective from Malaysia
}

\author{
Mathana Amaris Fiona Sivaraman, Siti Nurani Mohd Noor \\ Department of Science and Technology Studies, Faculty of Science, University of Malaya, Kuala \\ Lumpur 50603, Malaysia
}

\begin{abstract}
Background: The use of embryos in embryonic stem cell research (ESCR) has elicited ethical controversies as it entails the destruction of 5-day old human embryos to harvest stem cells.

Objective: To explore the ethical positions of Islam, Buddhism, Hinduism, and Catholicism concerning the use of (1) left-over embryos from in vitro fertilization (IVF) also known as 'surplus' embryos and (2) 'research embryos' which are created by scientists to conduct research using embryonic stem cells.

Methods: The opinions of religious leaders of Buddhist, Hindu, and Catholic faiths in Malaysia pertaining to ESCR were examined via in-depth, semi-structured interviews while Islamic responses are collected from local writings related to the derivation of fatwa on this issue. Participants' responses on the ethics of human stem cell research are presented as a reflection of various scriptural texts of these four religions. These are presented and supported with the help of international bioethics literature and focus on the use of 'surplus' embryos and 'research' embryos.

Results: Islamic ethics deviate from Hindu and Buddhist teachings regarding saving of research embryos that have been created specifically for research and are considered as human lives only after 120 days fertilization. Hindu and Buddhists also underscore the sanctity of human life, but give priority to the alleviation of suffering in living adult humans. They generally encourage ESCR. Research is a knowledge-seeking endeavor considered noble by Islam. This is also a concept within Hindu and Buddhist philosophy; in particular, when potentially beneficial research goals are the basis. Catholicism also emphasizes sanctity of human life, but stresses also the inviolability of embryos from the moment of conception.

Conclusion: Embryonic stem cell research is permissible and encouraged according to Hindu and Buddhist perspectives in view of the potential benefits of such research to society, with some reservations. This is similar to Islamic views on the ethics of ESCR. However, Catholicism differs from all the other three religions; it appears to discourage research in this field because of the likely violation of a sacred principle in Catholic teachings.
\end{abstract}

Keywords: Bioethics, embryo, ethics, religion, sanctity of life, stem cell research

Embryonic stem cells are derived from blastocysts (4-5 days postfertilization) [1]. Their pluripotent nature, which is their ability to differentiate into all cell derivatives of the human body and generate into various cell types, makes them useful in research that has widespread implications on biology and regenerative medicine. Stem cell research has been particularly mentioned as potentially useful for treatment of Parkinson's disease, multiple sclerosis,

Correspondence to: Mathana Amaris Fiona Sivaraman, Department of Science and Technology Studies, Faculty of Science, University of Malaya, Kuala Lumpur 50603, Malaysia. E-mail: fatima@siswa.um.edu.my myocardial infarction[2], Alzheimer's disease, spinal cord injury, cancer, and juvenile-onset diabetes [3].

In Malaysia, scientists currently use human adult stem cells. However, in anticipation of ethical issues, should scientists advance into human embryonic stem cell research, the 2009 Guidelines for Stem Cell Research and Therapy were prepared. Included within the guidelines is the Islamic ethicoreligious position for the use of human Embryonic Stem (hES) cells in research [4]. Accordingly, research on human embryonic stem cells is allowed, but limited to the use of surplus embryos, such as embryos leftover from infertility treatments. The creation of human embryos solely for research by any means including assisted 
reproductive technology or through somatic cell nuclear transfer (SCNT) is prohibitedin Malaysia [4].

Malaysia has a plurality of faiths, believes and traditions of Islam, Buddhism, Hinduism, and Catholicism in its multicultural society. The majority are Muslims who constitute $61.3 \%$ of the population [5]. The rest are made up of Buddhists (19.8\%), Christians (9.2\%), and Hindus (6.3\%) [5]. In Malaysia, like in many countries, moral concerns regarding ethics of research on human embryonic stem cells are being discussed. The importance of multireligious participation in ethical deliberation in this country has been noted by Fujiki and Macer who feel that all communities in multicultural Malaysia would do well to understand bioethical issues to participate fully in developing suitable ethical guidelines [6]. We focused on inclusion of opinions from all major faith groups in Malaysia[7]. Significant published work has also been reviewed from Asia and beyond to document various religious perspectives on organ transplantation [8], potential human cloning [9-10] and genetic engineering [11].

On the subject of embryonic stem cell research (ESCR), one need not look further than neighboring Singapore to find that opinions of multifaith groups are also given substantial consideration elsewhere. The Singapore Bioethics Advisory Council (BAC), for instance, had sought viewpoints of several religious councils when completing its 2002 report on the "Ethical, Legal and Social Issues in Human Stem Cell Research, Reproductive and Therapeutic Cloning” [12].

This paper examines the ethics of utilizing two different sources of embryos both created via IVF, namely (1) excess or leftover embryos from infertility treatments denoted as 'surplus embryos', and (2) embryos created specifically for research purposes or termed 'research embryos'. Surplus embryos are expected to carry a different, perhaps, 'lighter', moral/ethical connotation from research embryos. Surplus embryos are not intentionally created, but are readily available for use by scientists, whereas research embryos are specially created by the scientists to conduct research. The creation of the latter may go against the principle of respect for the dignity of human beings. Most writers argue that, while using research embryos is regarded as unethical, the use of surplus embryos is deemed ethically acceptable. The use of surplus embryos is ethical because this demonstrates that "proper respect" is given to these entities by using them still for good reasons, rather than discarding them [13] and letting them go to waste [14]. The United States National Bioethics Advisory Commission (USNBAC) also states that, research that inevitably involves the destruction of surplus embryos is acceptable because it may develop cures for life-threatening or severely debilitating diseases [15].

Past studies have discussed various views on the moral status of an embryo. Are such embryos to be accorded similar moral/ethical status as human beings or does their status increase gradually as they grow in utero or as a culture? [16-18]. Should moral protection be accorded to embryos from the moment of fertilization or should it be only recognized later? Twinning, at a later embryonic stage, has been used to suggest that embryos presumably lack the ability at this point to decide on this, and can thus be assumed to have no consciousness, which is a basic function of humans [19]. Biologically, it has been argued that the moral concern of harming the embryo does not arise because a 5-day old embryo has not developed the primitive streak as a precondition for a developing conscious being. Thus, it is acceptable to use surplus embryos for research rather than discard them [13]. Outka's 'nothing is lost principle' states two conditions; (1) the innocent will die in any case and, (2) another innocent life can be saved by not letting it die. Here, the surplus embryos satisfy the first condition and innocent lives suffering from diseases may be helped to satisfy the second one [20].

The USNBAC contains testimonies of religious leaders on ESCR [21]. Among others, Sachedina claims that according to Islam, it is an act of faith to carry out ESCR for maintaining health [22]. Farley, representing liberal Catholics, argues that ESCR can be carried out to promote human well-being [23]. Other liberal Catholics, including Jean Porter and Christian Kummer, also appear to support parts of ESCR [24].

ESCR appears to be in accordance with the Buddhist tenet of seeking knowledge and alleviating human suffering. However, some Buddhist scholars have shown that it actually constitutes an element of harm [25]. Keown, a renowned writer on Buddhist ethics, points out that Buddhism does not support research on human embryos that entails the destruction of human life [26]. In a well-reasoned paper, Promta makes a distinction between Buddhist personal and social ethics in Buddhism. The use of stem cells in research, which could mean destroying 'life', may be 
viewed as "socially" moral if it is intended to cure the disease of a human person, but this contradicts with Buddhist "personal" ethics, which emphasizes that destroying the embryo is a violation of its right to life [27]. The fundamental precept of Buddhism against harming and killing is also recognized by the Singapore Buddhist Federation, which supports ESCR that has the intention of helping humankind [12].

Hindu deliberations may be found in Swami Tyagananda's lecture where the destruction of life is held as bad karma unless the act is unavoidable and carried out for the 'greater good' of humanity [28]. The Singapore Hindu Endowments Board allows the use of stem cells from 5-day old embryos to establish stem cell cultured lines. It accepts the use of embryonic stem cells aimed at protecting life and finding cures for diseases [12].

As far as we know, no previous study has been conducted that collects multireligious viewpoints on the ethics of the use of surplus and research embryos in this part of Asia. A previous study by Foong on the moral/ethical issues of stem cell research and human cloning has included interviews with religious leaders, priests, and scholars from Muslim, Buddhist, Hindu, Catholic and Sikh faiths in Malaysia [29]. However, Foong did not enter into ethical deliberations on the use of surplus and research embryos. However, western bioethics workers have shown much more interest in this field. This study examined controversies regarding ESCR, focusing on the fact that embryos are eventually destroyed during the process of research. The ethical stances of religious leaders from the Buddhist, Hindu, and Catholic groups in Malaysia and the published position of Islamic leaders regarding the use of surplus embryos and research embryos are also explored in this paper.

\section{Method}

Semi-structured, in-depth, face-to-face interviews were conducted with religious representatives to gain understanding of this subject matter [30]. We formulated a structured interview guide. Questions were developed to gain clear views from the participants regarding ESCR and in regards to the use of surplus embryos and research embryos. This study conforms to ethical recommendations of the International Committee of Medical Journal Editors. Informed consent to publish this manuscript was obtained in writing from all interviewees.
Religious leaders and representatives from the Buddhist, Hindu, and Catholic communities were interviewed. There are many denominations within the Christian faith with conflicting views. However, only the Catholic perspective was explored because it represents $40 \%$ of the 2.2 million Christians in Malaysia [31].

Four Buddhist scholarly monks and leaders, four Hindu leaders, and three Catholic priests participated in this study. All participants had vast experience and knowledge, and had made significant contributions on ethics committees and interfaith councils. Informed consent was given in writing to use their information and publish it. Respondents expressed their views and understanding of various sacred texts and holy books in respect of ESCR, and care was taken to exclude any personal moral reasoning. Interviews were conducted in English between May to December 2012 and were audio-recorded and transcribed.

Interviews were not conducted with Muslim authorities because there is current published consensus on these issues. Muslims in Malaysia formally belong to the Sunni-Shafie school of thought. Responses were selected from local published material that focuses on the moral and ethical status of the human embryo.

\section{Results}

The official Islamic position on ESCR is that it is allowed only if conducted on surplus embryos. The use of embryos developed for research is prohibited. Generally, almost all Buddhists scholars approved fully of ESCR and do not see any moral/ethical differences between the use of surplus or research embryos. One Buddhist leader did not agree with the use of research embryos.

All Hindu representatives approved of ESCR, but limited it to using only surplus embryos. They agreed that the use of research embryos should be prohibited. All Catholic representatives totally disapproved of ESCR.

\section{Discussion}

This section discusses the rationale and reasoning that supports the Islamic, Buddhist, Hindu, and Catholic ethical responses on ESCR.

\section{Islamic ethics}

Malaysia is a multicultural and religious society. The Federal Constitution of Malaysia states that Islam 
is the religion of the Federation [32], but other religions are allowed to be practiced freely.

The institutionalizing of Islam is significant in Malaysia's public domain. This is illustrated in the derivation of Islamic rulings or fatwas to address and monitor controversial issues in biomedical research and in its applications that might affect Muslims. Fatwas are formulated by various state fatwa councils as well as the National Fatwa Council. A fatwa has declared that the use of surplus embryos for stem cell research is allowed, but not the use of those specifically developed for research [33]. This fatwa is explicitly included in the national guidelines for stem cell research and stem cell therapy [4]. The official guidelines developed by the Ministry of Health take into account 'the needs of scientists, researchers, clinicians, the multiethnic communities in Malaysia, the religious authorities, and the current relevant agencies regulating laboratories, manufacturing, pharmaceuticals and biological therapies' [34]. Accordingly, Muslim jurists allow the use of excess embryos from IVF treatment with the consent of the Muslim couple, provided they have completed their family.

Some Malaysian writers noted that the plurality of Islamic views, regarding when human life begins, has made the Islamic ethics of ESCR irresolvable [35]. The legal verdict related to in vitro fertilization (IVF) and stem cell research may be stated as not impermissible, but 'not encouraged' (makhruh). The Sunni school of thought, to which Malaysian Muslims generally belong, have adopted the resolution of the Muslim World League which takes the majority view that "ensoulment" takes place 120 days after fertilization [36];

"And indeed We created man from a quintessence of clay. Then we placed him as a small quantity of liquid (nutfa) in a safe lodging firmly established. Then we have fashioned the nutfa into something which hangs (alaqa). Then We made alaqa into a chewed lump of flesh (mudgha). And We made the mudgha into bones, and clothed the bones with flesh. And then We brought it forth as another creation. So blessed be God, the best to create" (Quran 23:12-14).

The process of "ensoulment" is given further as "and breathe into him of His spirit" (Quran 32:9) and supported with a Hadith or the sayings of the
Prophet Muhammad (pbuh) as reported by his companion;

"Verily your creation is on this wise. The constituents of one of you are collected for forty days in his mother's womb in the form of blood, after which it becomes a clot of blood in another period of forty days. Then it becomes a lump of flesh and forty days later Allah sends His angel to it with instructions concerning four things, so the angel writes down his livelihood, his death, his deeds, his fortune and misfortune."

The above scriptures have been decisive on the ruling on abortion in Malaysia, which is prohibited after the 'third fortieth' (120th) day. This is agreed by Shari'ah jurisprudence and termination of pregnancy is only permissible when the mother's life is in danger or other necessities deemed in accordance with the Shari'ah principle that orders committing the lesser of two evils [37, 38]. This principle would, presumably, apply also after the 120th day.

Writers have also referred to the above Quranic verse and the Hadiths to suggest that the womb provides the environment for development of a 'complete' human being and therefore embryos in the laboratory cannot be the same as a fetus in the womb $[35,39]$. The absence of uterus in IVF embryos takes away the moral/ethical rights of those embryos. Sidiqqi points out that the Shari'ah makes distinctions between actual and potential life. A fertilized ovum in a petri dish has potential to grow to a human being, but it cannot survive as a human being as it is not in its natural environment, a woman's womb [39].

Stem cell and embryo research have not faced much resistance in Arab and Islamic countries like Egypt, Iran, and Turkey. Not only because of the nature of Islamic medical ethics, which encourages seeking of knowledge [40], but also because of the concept of when life begins [22, 41].

A minority of Islamic jurists hold that "ensoulment" takes place during the first 40 days of embryo development, and therefore the 40-day limit is preferred to be on the safe side. This also implies that research that utilizes 5-day old embryos is not held as being unethical [40]. A survey of Muslim scholars by Eich also found that a majority do not consider embryos in early developmental stage as a human person [42]. The importance of saving lives in Islamic thought often quotes the following verse [43]: 
"Whosoever saves the life of one [human], it shall be as if he saved the life of all humankind" [Quran 5:32]

If ESCR can relieve suffering of people, then it is conceived an obligation or fardhu kifayah [39]. According to this, it becomes a duty for the scholars and scientists to assist those in society who can benefit from that knowledge. Delivering good deeds is in accordance with the principle of maslaha [40]. Research may be conducted on surplus embryos created from IVF that otherwise would be discarded. Letting the surplus embryos die without utilizing them when able to do so, and save potential human lives, is a form of killing by itself [44]. Protecting and saving the life of a human outweighs any ethical conscience associated with the use of the human embryo, which will die in the process.

\section{Buddhist ethics}

There seems to be a common ground concerning the use of surplus embryos and it is permitted by Buddhist and Hindu leaders interviewed in this study. It is one form of the concept of donation. In line with the notion of Dana, which means charity and generosity in Buddhism, donating surplus embryos for research represents good intentions, empathy, and the desire to save human lives. The act of saving lives, even at the risk of sacrificing one's life for the wellbeing of others, is regarded as a high virtue [45].

Almost all Buddhist respondents agreed that ESCR should be supported based on good intentions of researchers, seeking to help humanity. The concept of early embryonic life does not appear to be an obstacle to ESCR. According to them, life only begins when there is consciousness or there is a reaction to stimuli. The use of a 5-day old embryo therefore does not constitute destroying life, and does not violate the first Buddhist precept, which discourages acts that involve harm to others. They additionally note that killing is largely associated with an act that is premeditated by bad motives and usually laden with anger. None of this applied to the use of ESCR. One Buddhist leader differed in his opinion on the stage at which life actually begins. He stresses that 'life begins immediately after fertilization and as such regards the early embryo as a living entity. Human birth is additionally held as 'precious' and 'rare' and this strengthens the notion of the sacredness of human life no matter how early it appears. However, in view of the benefits of research, he agreed that it may be better to use surplus embryos rather than allowing them to be discarded, justifying this by 'the embryo is going to die anyway'. He, however, strongly disapproved of the use of research embryos, declaring that it denotes disrespect for human life.

The aim of research was held highly important by all Buddhist participants. According to Keown, Buddhism places emphasis on the value of knowledge (prajna), and the act of compassion (karuna) [26]. The Malaysian Ti-Ratana Buddhist Society pointed to Buddha's teachings regarding the Four Noble Truths that acknowledges the need to study diseases in search of cures, thereby demonstrating compassion through the alleviation of the suffering that diseases always bring [45].

One of the Buddhist leaders highlighted that any decision on a contentious matter must be made in reference to the following: the Five Precepts of not harming beings with a conscious response, karma, rebirth, and intention. Buddhism believes in rebirth. The faith views the new being as bearing the karmic identity of a deceased and therefore deserves the moral respect of any human being [26]. When the body dies, the energies or consciousness do not die, but take on another form of life resulting in a continuum [45]. For conception to take place, three things must invariably occur, the sexual union of parents (sannipatita), the mother in fertile period (utuni), and the presence of the gandhabba (consciousness of being) [46]. In view of this, three respondents held the opinion that the practice of ESCR is not immoral as a being begins at a later stage.

\section{Hindu Ethics}

Buddhism and Hinduism are guided by the Law of Karma. The Hindus are also guided by Dharma. Dharma is the ethical code for behavior, while karma is a causal law in which all good and bad acts will face consequences in the next life [47].

Both religions also place importance on ahimsa, the nonharming principle, and thus hold reservations regarding destruction of life, which generates bad karma [26]. Destruction of the embryo may be considered as a bad karma, but if ESCR is conducted with the intention of saving lives, it would be perceived as a good karma.

Two Hindu respondents said that if the research is intended for a good cause, then it should be allowed, but must be limited to using surplus embryos. Donating 
surplus embryos for research is in alignment with certain scriptural teachings that state that they must be used for a good cause.

One leader observes that ESCR should be permitted only if it abides by the Laws of Karma, Dharma and the principle of ahimsa. The extraction of stem cells from a 5-day old embryo is not considered as killing because it is still in its vegetative state and the soul is not present. According to scriptures like Thevaram and Thirumanthiram, "ensoulment" begins 90 days after fertilization. At least two respondents therefore regard a 5-day old embryo as being merely in a vegetative state and not a human being.

Interestingly, the second respondent refers to the Vedas, Manudharmashastra, Thirumanthiram, and Periya Puranam and opted to view the issue from the perspective of donation. The story in Periya Puranam recounted how a hunter donated both his eyes upon seeing the bleeding eyes of Lord Shiva's deity. The act of donation and sharing is further encouraged in the event where there is excess of material goods. The permissibility of the use of surplus or excess embryos may hence be viewed in the same way.

A third respondent, however, stresses that human life begins at the time of fertilization. As outlined in the sacred text, Caraka Samhita,

"...In the event of intercourse thus described, the individual soul (jiva) descends into the union of semen and (menstrual) blood in the womb in keeping with the (karmically produced) psychic disposition (of the embryonic matter)" [48]

Here conception is believed to be the beginning of the soul's rebirth from a previous life [25]. Hindus believe the soul (atman) transmigrates from one life to another and thus the present life is seen as a transition between the previous one and the next [47]. The embryo is viewed as a 'spirit-matter composite' from the very moment of fertilization. This seems to give researchers no provision to extract stem cells; even from a 5-day old embryo. However, when discussing the sacredness of embryonic life, the third respondent recalls the South Indian Hindu tradition that regards the egg as nonvegetative, but that it has the potential to develop into a living being. The fertilized ovum or embryo should therefore be recognized as an advanced stage in human life representing a transition from a previous one, and hence worthy of protection. Hence, while establishing this fact, she also points out that some Hindu scriptures do allow abortion if the mother's life is in danger. Accordingly, Hindu teachings related to Dhayai or parivu, which means compassion and caring, is respected when greater consideration is given to the mother's life. In this vein, this analogy could be applied to again endorse the use of surplus embryos.

As noted by Lipner, Hinduism is generally protective of the embryo. The slayer of the embryo is regarded as wicked and despicable by Brhadaranyaka Upanishad (8-9 B.C.E) and the Kausitaki Upanishad also regards abortion as an act of murder [48]. However, Hindu ethics balances this view by adopting the Dhayai, which encourages compassion towards the mother whose life may be endangered. This line of thinking is observed when the third respondent argues that the use of surplus embryos may be allowed considering that many lives can be saved through ESCR research.

While not disapproving ESCR, the fourth Hindu leader asks that 'the least possible destruction" be used when conducting such research. This would be in accordance with the concept of ahimsa. He further disclosed that decisions on contentious issues affecting Malaysian Hindus are often made in consultation with rulings made by the government of India.

\section{Catholic ethics}

Unlike Buddhist and Hindu leaders, all three Catholic priests were well versed with ethical issues regarding ESCR. All hold the official position declared by the Vatican, which opposes ESCR whether via the use of surplus embryos or research embryos. This is the universally accepted position of all Catholic churches worldwide, and the respondents conceded not holding a different ethical standpoint on this matter.

Human life begins from the moment of fertilization, is held sacred from thence onwards, and must be accorded protection and dignity. There is no divine revelation about soul, but the Catholic participants have taken the position that the soul is present from the moment of fertilization.

The conceptus deserves equal respect and dignity as a human being. This is given in the official Declaration on Procured Abortion 1974, paragraph 12 states: 
"From the time that the ovum is fertilized, a life is begun which is neither that of the father nor of the mother; it is rather the life of a new human being with his own growth" [49]

A statement from the Vatican document, Donum Vitae in 1987 (No. 5 I 5) responds to the use of embryos obtained by IVF or any other means for research purposes, "It is immoral to produce human embryos destined to be exploited as disposable biological material" [50]

It should be noted that the Pontifical Academy of Life has released the 'Declaration on the Production and the Scientific and Therapeutic Use of Human Embryonic Stem Cells' in the year 2000 [51]. Entrenched within this Declaration is the Catholic view of the moral/ethical status of embryonic life, '[the] human embryo from the moment of union of sperm and egg is a well-defined identity...and thus cannot be considered as a mass of cells'.

Pope John Paul II has expressed that [research] "insofar as they involve the manipulation and destruction of human embryos, are not morally acceptable, even when their proposed goal is good in itself...but rather make use of stem cells from adults...in order to respect the dignity of every human being even at embryonic stage" [52].

Dignitas Personae endorsed by Pope Benedict in 2008, reiterates that using embryos left from infertility procedure for treating diseases is unacceptable because embryos are treated as biological material resulting into their own destruction [53]. The practice of IVF itself faces objection from Catholic faith as a huge number of embryos are sacrificed in each IVF cycle. Such an act is noted to be against the grounds of natural procreation and the unity of marriage.

The Vatican encyclicals, and Book of Genesis verse 1:26-28 and verse 9:6 were also referred to by Catholic leaders interviewed, citing that human persons are created in God's image and likeness and, hence respect ought to be given. The provisions assert that procreation must be upheld through natural means and the church is against the technique of IVF in principle.

Two respondents advocated the principle of 'the end does not justify the means' to reject the proposition that endeavors in ESCR meant attaining cures and hence promoting quality of life. The third respondent alluded to a clause in the Bible i.e. the Book of Mark verse 8:36 and Book of Matthew verse 16:26 that states "What does it profit a Man if he wins the whole world but suffer the loss of his own soul?"
While the Buddhists and Hindus are guided by a plethora of scriptures, the Holy Bible remains as the primary source of Catholic teachings, besides the encyclical letters and positions pronounced by the Vatican. These sources are unreservedly accepted by Catholic churches in Malaysia and throughout the world.

\section{Conclusion}

Each religion believes in the sacredness of human life and the moral duty not to harm a human being. While the very practice of ESCR itself is seen as a good act in view of its overriding aim to seek cures for diseases, the nature of research entailing the destruction of human embryos, has elicited ethical controversies. The question as to when an embryo is entitled to full moral protection has been highlighted in the present study. Taking stock of the ethical viewpoints of Buddhist and Hindu leaders, it appears that the donation of leftover IVF embryos for research that may lead to saving lives has been accepted. Islamic deliberations also point in this direction. Islamic standpoints on ESCR revolve around the notion of sanctity of life and it is conceived that it begins later in embryonic life, well after fertilization. The obligation to save lives via stem cell research is also a strong factor that supports the Islamic ethics of ESCR.

Our findings show that Catholicism firmly opposes ESCR, regardless of the source of embryos. Catholics justify their objections strongly by the inviolability of life that begins in an embryo at the time of fertilization.

By contrast, it is observed that Hindu and Buddhist respondents take up positions that are more complex and are more inclined to accept the concept that ESCR leads to goals of saving lives, alleviating suffering and other noble intentions of research. Two broad ethical guiding principles may be derived from Buddhist and Hindu thinking concerning human embryonic stem cell research. Firstly, Hindu and Buddhist ethics support efforts of saving human lives. Knowledge seeking is also held in high regard within both Hinduism and Buddhism. Good intention that should drive stem cell research and knowledge seeking activities are held as noble and at high esteem by both religions and traditions. Secondly, the concept of donation is employed when arguing the permissibility of using surplus embryos. They expand the arguments that in special circumstances allow abortion. The mother's endangered life must be given greater weight than that of the foetus. 
Our findings differ from Keown's paper in 2004 where he states that, generally, all Buddhists oppose research on human embryos [26]. Promta's reflection is especially enlightening because he gives a fresh interpretation of the philosophy of Buddhist social and Buddhist personal ethics [27]. We find this to be reflected in our study where a diversity of views is seen to exist within Buddhism and Hinduism. Interestingly, the religious leaders in this study embraced the advantage of not having a central authority. This encourages individuals to seek personal understanding from their scriptures. Given the varying opinions, it can be concluded that all Hindu leaders cautiously support the use of surplus embryos, but oppose the use of intentionally created research embryos. Buddhist leaders share similar views. On the other hand, it is clear that Catholic leaders do not permit any form of ESCR.

\section{Acknowledgements}

We thank the anonymous religious scholars that helped us to prepare this paper. This research was supported by the University of Malaya Grant Project no. PS023-2012A. The authors themselves hold no religious offices and have no conflicts of interest to declare.

\section{References}

1. Thomson JA, Itskovitz-Eldor J, Shapiro SS. Embryonic stem cell lines derived from human blastocysts. Science. 1998; 282:1145-7.

2. McLaren A. Ethical and social considerations of stem cell research. Nature. 2001; 414:129-31.

3. Braverman A, Steinbock B, Wilder B, Batzer F, Robertson J, Francis L. Donating spare embryos for stem cell research. Fertil Steril. 2009; 91:667-70.

4. MOH. Malaysian guidelines for stem cell research and therapy. 2009; http://www.crc.gov.my/guidelines/pdf/ B/MALAYSIAN\%20GUIDELINES\%20FOR\%20 STEM\%20CELL\%20RESEARCH\%20AND\% 20THERAPY\%202009\%20.pdf Accessed 13 October 2013.

5. Department of Statistics Malaysia. Chart 12: Percentage distribution of the population by religion, Malaysia, 2010. 2012; http://www.statistics.gov.my/ portal/index.php?option=com_content $\&$ view $=$ article\&id=1215\&Itemid=89\&lang=bm. Accessed 13 October 2013.

6. Fujiki N, Macer D. Bioethics in Asia. Eubios J. Asian Inter Bio. 2000:66-9.
7. Robson NZMH, Razack AH, Dublin N. Review paper: organ transplants: ethical, social, and religious issues in a multicultural society. Asia Pac J Public Health. 2010; 22:271-8.

8. Tai MC-T. An Asian perspective on organ transplantation. Tzu Chi Med J. 2009; 21:90-3.

9. Roetz H. Cross-cultural issues in bioethics: the example of human cloning. Editions Rodopi; 2006.

10. Campbell C. Religious perspectives on human cloning. Rockville, Maryland: National Bioethics Advisory Commission; 1997.

11. Pfleiderer G, Brahier G, Lindpaintner K. Beyond playing God: critical religious genethics for pluralistic societies. In: Pfleiderer G, Brahier G, Lindpaintner K, editors. GenEthics and religion. Basel: Karger; 2010.

12. Singapore BAC. Ethical, legal and social issues in human stem cell research, reproductive and therapeutic Cloning. 2002. p. 1-11.

13. Manninen BA. Respecting human embryos within stem cell research: seeking harmony. In: Gruen L, Grabel L, Singer P, eds. Stem cell research: the ethical issues: Blackwell Publishing; 2007.

14. Hug K. Sources of human embryos for stem cell research: ethical problems and their possible solutions. Medicina (kaunas). 2005; 41:1002-10.

15. NBAC. Ethical issues in human stem cell research. Rockville, Maryland: National Bioethics Advisory Commission (NBAC) Volume I; 1999.

16. DeGrazia D. Must we have full moral status throughout our existence? A reply to Alfonso Gomez-Lobo. Kennedy Inst Ethics J. 2007; 17:297-310.

17. Hug K. Therapeutic perspectives of human embryonic stem cell research versus the moral status of a human embryo-does one have to be compromised for the other? Medicina (kaunas). 2006; 42:107-14.

18. Pardo R, Calvo F. Attitudes toward embryo research, worldviews, and the moral status of the embryo frame. Science Commun. 2008; 30:8-47.

19. Marquis D. The moral principle objection to human embryonic stem cell research. In: Gruen L, Grabel L, Singer P, eds. Stem cell research: the ethical issues: Blackwell Publishing; 2007:51-66.

20. Outka GH. The ethics of human stem cell research. Kennedy Inst Ethics J. 2002; 12:175-213.

21. NBAC. Ethical issues in human stem cell research. Rockville, Maryland: National Bioethics Advisory Commission Volume III; 2000.

22. Sachedina A. Testimony of Abdulaziz Sachedina. Rockville, Maryland: National Bioethics Advisory Commission Volume III; 2000:G1-G6. 
23. Farley MA. Testimony of Margaret A. Farley. Rockville, Maryland: National Bioethics Advisory Commission Volume III; 2000:D1-D5.

24. Reichhardt T, Cyranoski D, Schiermeier Q. Religion and science: studies of faith. Nature. 2004; 432:666-9.

25. Knowles LP. Religion and stem cell research. Stem Cell Network; 2009. http://www.stemcellschool.org/pdf/ Religion-and-Stem-Cell-Research.pdf Accessed 7 November 2013.

26. Keown D. 'No Harm' applies to stem cell embryos: one Buddhist's view. Science and Theology News. 2004; http://www.beliefnet.com/News/ScienceReligion/2004/04/No-Harm-Applies-To-Stem-CellEmbryos-One-Buddhists-View.aspx Accessed 7 November 2013.

27. Promta S. Human cloning and embryonic stem cell research. Eubios J Asian Inter Bioethics. 2004; 14: 197-9.

28. Tyagananda S. Stem cell research: a Hindu perspective. Massachusetts: MIT Religious Activities Center; 2002.

29. Foong P. Human embryonic stem cell (HESC) research in Malaysia: multi-faith perspectives. Asian Bioethics Review. 2011; 3:182-206.

30. Patton MQ. Qualitative evaluation and research methods. 2nd ed. Newbury Park, California: Sage Publications; 1990.

31. Herald Malaysia. Catholics population hit 1 million mark in Malaysia. Kuala Lumpur: Herald Newsletter; 2012.

32. Fernando JM. The position of Islam in the constitution of Malaysia. J Southeast Asian Studies. 2006; 37: 249-66.

33. Department of Islamic Development Malaysia. Ruling on Therapeutic Cloning and Stem Cell Research. 2005; http://www.e-fatwa.gov.my/fatwa-kebangsaan/hukumpengklonan-terapeutik-dan-penyelidikan-sel-stemstem-cell. Accessed 21 November 2013.

34. Jamal RA. Abstract book: Guidelines on stem cell research and therapy in Malaysia: restrictive or permissive? 1st National Stem Cell Congress in Malaysia: Ministry of Health \& National University Malaysia Medical Molecular Biology Institute; 29-30 October 2012.

35. Nor SNM. Human genetic technologies and Islamic bioethics. In: Pfleiderer G, Brahier G, Lindpaintner K, editors. Gen Ethics and Religion. Basel: Karger; 2010.

36. Nordin MM. Human genetic and reproductive technologies-an international medico-legal-religious impasse? Bangladesh J Med Science. 2011; 10:1-10.

37. Muhammad Husin A, Mohammad AB, Mohd Nor AH,
Laluddin H, Samuri MAA. Abortion in Malaysian Law: a comparative study with Islamic jurisprudence advances in natural and applied sciences. 2013; 7 : 39-50.

38. Tengku Zainudin TNA. Abortion and the right of the foetus to live. Malaysian Institute of Islamic Understanding IKIM Law J. 2001; 5:93-146.

39. Siddiqi M. An Islamic Perspective on Stem Cell Research. 2002; http:/www.islamicity.com/articles/ Articles.asp?ref=IC0202-404. Accessed 15 November 2013.

40. Rispler-Chaim V. Between Islamic Law and Science: Contemporary Muftis and Muslim Ethicists on Embryo and Stem Cells Research. Comparative Islamic Studies. 2006; 2:27-50.

41. Sachedina A. Islamic Perspectives on Cloning. n.d.; http://people.virginia.edu/ aas/issues/cloning.htm. Accessed 15 November 2013.

42. Eich T. Muslim Voices on Cloning. ISIM [International Institute for the Study of Islam in the Modern World] Newsletter. 2003;12:38-9.

43. Al Hayani FA. Muslim perspectives on stem cell research and cloning. Zygon. 2008; 43:783-95.

44. Aksoy S. Making regulations and drawing up legislation in Islamic countries under conditions of uncertainty, with special reference to embryonic stem cell research. Journal of Medical Ethics. 2005; 31:399.

45. Dhammananda KS. What Buddhists believe. Expanded 4th ed: Ti-Ratana Buddhist Society Malaysia; 2002.

46. Boisvert M. Conception and intrauterine life in the Pali Canon. Studies in Religion/Sciences Religieuses. 2000; 29:301-11.

47. Firth S. End-of-life: a Hindu view. Lancet. 2005; 366:682-6.

48. Lipner JJ. The classical Hindu view on abortion and the moral status of the unborn. Hindu ethics: Purity, Abortion, and Euthanasia. Albany: State University of New York Press; 1989:41-70.

49. John Paul II. Congregation for the Doctrine of Faith Declaration on Procured Abortion 1974. 1974; http:// www.vatican.va/roman_curia/congregations/cfaith/ documents/rc_con_cfaith_doc_19741118_declarationabortion_en.html. Accessed 3 November 2013.

50. John Paul II. Congregation for the Doctrine of the Faith Instruction on Respect for Human Life in Its Origin and on the Dignity of Procreation Replies to Certain Questions of the Day (Donum Vitae). 1987; http://www.vatican.va/roman_curia/congregations/ cfaith/documents/rc_con_cfaith_doc_19870222_ respect-for-human-life_en.html. Accessed 5 November 
2013.

51. Pontifical Academy for Life. Declaration on the Production and the Scientific and Therapeutic Use of Human Embryonic Stem Cells. 2000; http://www. vatican.va/roman_curia/pontifical_academies/acdlife/ documents/rc_pa_acdlife_doc_20000824_cellulestaminali_en.html. Accessed 5 November 2013.

52. John Paul II. Address of the Holy Father John Paul II to the $18^{\text {th }}$ International Congress of the Transplantation Society. 2000; http://www.vatican.va/ holy_father/john_paul_ii/speeches/2000/jul-sep/ documents/hf_jp-ii_spe_20000829_transplants_ en.html. Accessed 6 November 2013.

53. Benedict. Congregation for the Doctrine of the Faith: Instruction Dignitas Personae on Certain Bioethical Questions. 2008; http://www.vatican.va/roman_curia/ congregations/cfaith/documents/rc_con_cfaith_doc_ 20081208_dignitas-personae_en.html. Accessed 3 November 2013. 